J. OF PUBLIC BUDGETING, ACCOUNTING \& FINANCIAL MANAGEMENT, 19 (2), 245-267 SUMMER 2007

\title{
PUBLIC PENSION FUND GOVERNANCE PRACTICES AND FINANCIAL PERFORMANCE
}

\author{
William G. Albrecht, Hannarong Shamsub, and
}

Nicholas A. Giannatasio*

ABSTRACT. This study is a follow up of an earlier investigation concerning the effects of governance practices and investment strategies on public pension fund risk adjusted financial performance. Specifically, the inquiry uses three cross sectional national surveys of state and local government retirement systems to determine how governance practices in terms of system policies, board purview, and board composition impact abnormal returns. Results indicate that governance practices, particularly board purview over investment decisions, continue to have a direct negative impact on risk adjusted financial performance even after controlling for other factors.

\section{INTRODUCTION}

The objective of this study is to extend the work of Albrecht and Hingorani (2004) which examined the effects of governance practices and investment strategies on state and local government pension fund financial performance. In that investigation the researchers test the mediating theory of Useem and Mitchell (2000) who

* William G. Albrecht, Ph.D., is an Assistant Professor, Department of Political Science \& Public Administration, University of North Carolina at Pembroke. His research and teaching interests are in public finance, financial management and public pension funds. Hannarong Shamsub, Ph.D., is Labor Market Statistics and Research Consultant, Department of Employment Relations, Cayman Islands Government, Grand Cayman. His research interests are public finance and human development policies. Nicholas A. Giannatasio, Ph.D., is an Associate Professor, and Director of the Graduate Program in Public Administration, Department of Political Science and Public Administration, University of North Carolina at Pembroke. His research and teaching interests are in decision making, discretion and local governance.

Copyright $\odot 2007$ by PrAcademics Press 
hypothesized, tested, and found that the relationship between pension fund governance practices and investment performance was essentially indirect via asset allocation decisions. Substantive similarities between the studies include a) identical sources of governance and total return data, b) similar measures for both governance and investment strategy predictors, c) comparable single period time horizons for their analyses, and d) the use of Ordinary Least Squares (OLS) in estimating coefficients for multivariate models. Substantive differences consist of a) the historical time periods under consideration for each study, b) statistical tests for mediation, and c) the definition and subsequent measure of financial performance.

While Useem and Mitchell utilize total return as a pension outcome measure Albrecht and Hingorani follow Nofisnger (1998) in employing a separate "risk adjusted" standard defined as abnormal return. In the end, this latter difference emerges as the most significant as their pension outcome measure leads Albrecht and Hingorani to a conclusion different from Useem and Mitchell. In essence they found that while some evidence of a mediating data relationship did exist, governance practices continued to have a substantive direct impact on financial performance when controlling for risk. Their overall conclusion was that while direct and indirect governance effects are involved in the production of abnormal returns, direct effects essentially dominate the data generation process.

Given the above, this paper extends the work of Albrecht and Hingorani in two ways. First, multiple time periods are examined as a panel data set instead of a single year. Second, in order to deal with multiple time periods, a cross sectional time series approach is used in place of OLS as a multivariate procedure. OLS has a number of shortcomings when estimating panel data and we seek to correct for these deficiencies. However, OLS results are presented in the paper as a benchmark for comparison purposes.

The organization of the remainder of the article is as follows. First, the target population requirements and sample selection methods are discussed. Then variable descriptions, measurements, and relationships to financial performance are communicated before discussing the procedure and general hypothesis of the study. Univartiate, bivariate, and multivariate results are then presented. 
The paper concludes by discussing the relevance of the study and noting public policy implications.

\section{TARGET POPULATION AND SAMPLE SELECTION}

The target population requirements for this study have been previously detailed and are described here in brief. ${ }^{1}$ The target population may be broadly defined as all large state and local government pension systems in the United States and corresponding territories that fulfill the following requirements:

- The system is comprised of plans offering defined benefits only.

- The system is governed by a board of trustees or retirement board.

- The system is open and investing system assets.

Criteria one and two are invoked to remove influences emanating from outside decision makers such as defined contribution participants or external money managers that are hired to make all investment decisions on behalf of a system. The third prerequisite is intended to eliminate survivorship bias by excluding systems which are (a) not actually investing or (b) simply drawing down assets in anticipation of eventual termination.

Systems responding to the Public Pension Coordinating Council's (PPCC) 1997, 2000, and 2001 Surveys of State and Local Government Employee Retirement Systems were selected for a purposive sample. In discussing an earlier PPCC survey, Mitchell and Hsin (1997) state that "...there is no larger, more up-to-date, and more representative survey of state and local pension plans in the country; the federal government collects no centralized information of this type [though many have suggested it should] (p. 104)." The data for the 1997 and 2000 surveys are publicly available for purchase from the Government Finance Officers Association in an electronic format along with accompanying software packages titled PENDAT 1997 and PENDAT 2000, respectively. The data for the 2001 survey are also publicly available and free of charge from the PPCC's website. ${ }^{2}$ In most instances the data reflect fiscal year values. However, as discussed below, the dependent variable is measured on a calendar year basis.

The first survey contains pension information as of 1996 for 261 Systems (GFOA, 1997, p. 2). Of these, 223 meet the target 
population requirements given above. The second survey provides the same information regarding 246 public pensions as of 1998 (GFOA Research Center, 2000, p. 7). Two hundred funds are eligible given the parameters of this study. The third survey details similar information for 152 funds for 2000 (Harris, 2001, p. 3). Of these, 126 systems are in accordance with the target population requirements.

Because of the potential cross-sectional correlation and timewise autoregressive properties of panel data, the analysis is limited to systems reporting the necessary information for all variables of interest in each of the three surveys (Nofsinger, 1998). This limitation leaves 81 pension systems with data for each of the three years for a total of 243 observations.

\section{GOVERNANCE PRACTICES: VARIABLE DESCRIPTIONS, MEASUREMENTS, AND RELATIONSHIPS TO FINANCIAL PERFORMANCE}

Variable selection was determined primarily by a review of prior statistical investigations concerning state and local government pension fund financial performance. Specifically, the decision to include a particular governance practice in the study was generally, but not exclusively, based on the work of Albrecht and Hingorani (2004), Useem and Hess (2001), and Useem and Mitchell (2000). A notable exception exists in relation to whether or not the pension fund board has controlling authority over investments. Other empirical studies lending peripheral support for examining a governance practice include Munnell and Sunden (2001) and Mitchell and Hsin (1997). The decision to use abnormal return as a pension outcome measure was based on Nofsinger's (1998) study as to the influence of economically targeted investments on public pension risk adjusted financial performance.

Levels of measurement were determined by the type of response allowed for a particular PPCC 2001, 2000, 1997 survey question. In some cases previously examined governance practice variables were excluded from the analysis due to poor dichotomous splits which essentially restrict the sampling range. ${ }^{3}$ In other instances a particular governance practice was eliminated if the variable was either not measured or identically measured in each of the three surveys. ${ }^{4}$ 


\section{Financial Performance}

\section{Abnormal Return}

Abnormal return was calculated by first creating a benchmark portfolio return for each system "i" for each calendar year " $t$ " and then subtracting the benchmark return from the system's total return (time weighted) for each calendar year. Following Nofsinger (1998), the benchmark return was constructed by weighting returns to various indexes according to the reported asset allocation of the system for each survey (Nofsinger, 1998). For example, the 2001 total return of a fund with reported allocations of 50 percent in domestic equities, 40 percent in domestic bonds, and 10 percent in cash is measured against a 2001 benchmark portfolio of 50 percent in domestic equities, 40 percent in domestic bonds, and 10 percent in cash. Equation one below is a general result for the risk adjusted measure of financial performance:

$$
\text { Abnormal Return }_{\text {it }}=\text { Total Return }_{\text {it }}-\text { Benchmark Return }_{\text {it }}
$$

The asset classes and benchmark indexes used in the study are as follows:(a) domestic equities indexed by the S\&P 500, (b) international equity indexed by the Morgan Stanley EAFE Index, (c) domestic fixed income indexed by the Lehman Corporate and Government Bonds Index, (d) international fixed income indexed by the Salomon Brothers World Government Bond Index, (e) cash and short-term securities indexed by the US Treasury Bill, (f) real estate equity indexed by the Wilshire REIT Index, (g) alternative investments and other investment indexed by the NCREIF Property index, ${ }^{5}(\mathrm{~h})$ real estate mortgages indexed by the 15 year fixed mortgage rate. ${ }^{6}$

\section{Governance Characteristics}

\section{Investment Restrictions}

Various studies have investigated the effects of different types of investment restrictions on public pension investment performance. Typically the constraints have focused on three different aspects: required instate investment restrictions, use of prudent person or prudent expert rules in making investment decisions, and constitutional restrictions on investment practices. Until recently, investment restriction variables were generally introduced as controls for statistical investigations of economically targeted investment activity rather than for the strict examination of governance practices on financial performance. With limited exceptions, this latter aspect is 
a rather recent trend in public pension research and overall the results are somewhat mixed.

In examining the first type of restriction, Mitchell and Hsin (1997) found that pension systems which were required to devote a portion of their assets to state specific projects (e.g., to build stronger job and tax bases) earned lower total portfolio returns in the same period (e.g., 1990). However, the researchers do not replicate this finding statistically or substantively when using average total return over a five year period as a measure of financial performance. These results parallel that found in a more recent study by Munnell and Sunden (2001) who also found little evidence of consistent systematic explanations for instate investment (for either individual years 19911997 or for pooled data) effects on total return.

In terms of the second type of restriction Nofsinger (1998) found some evidence of a positive impact for systems implementing prudent standards in their investment practices on 1991 abnormal return. However, this finding did not persist over subsequent cross sectional OLS regressions of individual years (1991, 1992, 1993), nor did the result occur when the researcher used a combined sample regression technique. These results are similar to those found by Albrecht and Hingorani who use the 2000 survey and a series of OLS regressions to decompose the effects of governance practices and investment strategies on public pension fund risk adjusted financial performance. One possible explanation for the lack of a direct statistical link between prudent standards and financial performance is that all pension boards may de facto follow a variant of this policy (Mitchell \& Hsin, 1997).

When examining state constitutional investment restrictions Useem and Mitchell (2000) hypothesized and found that these types of constraints indirectly reduced total return via asset allocation strategies. Specifically, the investigators deduce that constitutional investment restrictions, all else constant, reduced equity allocations by 7.59 percent. Since equity strategies were determined to increase total return by as much as seven basis points the limitation was deemed to reduce this measure of financial performance.

A remaining empirical question is whether these results hold a) across time and b) for a risk adjusted measure of financial performance. In this study, "constitutional investment restrictions" was chosen as the survey item of interest. The variable was measured as a dichotomous variable with one denoting the existence 
of such a constraint and zero indicating otherwise. The general expectation is that constitutional investment restrictions exhibit a negative relationship with abnormal return. ${ }^{7}$

\section{Board Purview}

According to Useem and Mitchell (2000) retirement system trustees are usually not professional money managers, and hence may be unfamiliar with the considerations that go into making investment decisions. "Still, some pension fund boards fix the allocation of assets among classes of investments, and some even take a direct hand in picking the investments" (Useem \& Mitchell, 2000 , p. 497). Such inexperience may have a negative effect on financial performance and Albrecht and Hingorani (2004) do find some evidence of such occurrences when board members make asset allocation decisions. The PPCC's 2001, 2000, and 1997 surveys each include a consistent and single item for determining board authority in relation to investment decisions. In this study, "board purview over investment decisions" was measured as a dichotomous variable with one denoting use of the governance practice and zero indicating otherwise.

\section{Board Size and Composition}

Current research on corporate governance indicates that the size of corporate boards can affect company performance. For example, a study by Yermack (1996) suggests that boards with fewer directors achieve better financial results as firms with fewer members are more likely to dismiss ineffective Chief Executive Officers. Pension funds with smaller boards are hypothesized to display similar characteristics in dealing with their membership and thereby achieve higher levels of financial performance. ${ }^{8}$

In addition to board size, the composition of trustee membership might also be expected to affect investment performance. For example, Nofsinger (1998) finds some (inconsistent) evidence that direct agency costs exist when the interests of pension participants (through elected members) are not in line with that of taxpayers who are residual claimants of public pension fund surpluses and deficits. Albrecht and Hingorani (2004) also show that the percentage of the board appointed consistently reduces risk adjusted returns by approximately 2 basis points. ${ }^{9}$ 
Each of the three surveys provides information for the variables of interest. Specifically, in this study, "board size" was measured as the total number of trustees on a pension fund's board and the "percentage of board members appointed" was defined as (Number of Members Appointed/Total Number of Board Members) X 100.

\section{System Size}

In pension research assets are often used as a measure of system size, wealth, or other resources. Munnell and Sunden (2001) found that "large systems are likely to be more efficient in the management and administration [of system assets] and appear to earn higher [total] returns" (p. 159). To the extent that larger systems can capitalize on such efficiencies or economies of scale relative to investment activities the hypothesis here is that a positive relationship exists between system size and risk adjusted financial performance. In this study the measure was defined as an ordinal variable involving the following classifications: < \$100 Million; \$100 Million - \$999 Million; \$1.0 - \$9.9 Billion; and \$10+ Billion. ${ }^{10}$

\section{Portfolio Composition}

In terms of research, the proportion of assets invested in equity investments is often used to evaluate financial outcomes relative to total return. Reported results on state and local government pensions generally, but not always, indicate significant positive effects both in the short run and in the long run. ${ }^{11}$ These findings are consistent with general market conditions for the time period(s) being studied.

However, Nofsinger (1998), who used abnormal return in a panel data analysis did not find a statistically significant positive affect in relation to equity investments. And, Albrecht and Hingorani (2004) found evidence of a negative impact on risk adjusted financial performance. These contradictory results did not support a clear expectation as to direction. ${ }^{12}$

\section{PROCEDURE AND GENERAL HYPOTHESIS}

Prior to any form of examination, all variables were examined for accuracy of data entry, missing values, and fit between their distributions and the assumptions of mulitvariate analysis. Consistency checks revealed several reporting which are documented and illustrated in an earlier investigation. ${ }^{13}$ To improve pairwise 
linearity and to reduce positive skewness and kurtosis the total number of board members variable was logarithmically transformed.

In terms of analysis, first univariate statistics and simple counts were calculated. Then bivariate relationships between dichotomous governance practice variables and abnormal return were tested for each of the three surveys. Specifically, parametric tests were conducted to determine whether or not financial performance was different for systems (a) subject to constitutional investment restrictions, and (b) in which the board has controlling authority over investment decisions. In addition, simple correlation coefficients were calculated to examine the relationship of risk adjusted financial performance with continuous predictors. Finally, a multivariate analysis using a cross-sectional time series approach was used to examine the effects of governance practices on financial performance. The overall hypothesis was that governance practices have a statistically and substantive direct impact on the abnormal return criterion variable.

\section{Econometric Framework}

When dealing with cross-sectional time-series data, the error terms $e_{i t}$ incorporate the influence of omitted variables. This leads to a violation of the classical assumption that omitted variables are independent of the included variables and are independently distributed. The omitted variables in the cross-sectional time-series data can be classified into three groups: individual time-invariant variables, period individual-invariant variables, and individual time varying variables. ${ }^{14}$

The individual time-invariant variables are variables that are the same for a given cross-sectional unit through time, but vary across cross-sectional units. Examples are different characteristics of each pension fund. The period individual-invariant variables are variables that are the same for all cross-sectional units at a given point in time, but vary through time. Examples are national economic growth and monetary policy that impact the performance of pension funds. The individual time varying variables are variables that vary across crosssectional units at a given point in time and also exhibit variation through time. A good example is the difference in size of assets across pension funds. Size of assets for each fund also changes over time. 
To deal with the problem of these omitted variables, we estimate this data set by using a fixed-effect model and a random-effect model. The fixed-effect model assumes that the differences across units (e.g. pension funds) can be captured by the differences in constant terms. By comparison the random-effect model assumes that differences across units can be captured by parametric shifts in a regression function with a constant slope. In general form, the regression model in this study was specified as equation two below:

$$
\begin{aligned}
A R_{i t}= & b_{0}+b_{1} C_{C O N S T}+b_{2} \text { BRDINV }_{i t}+b_{3} \text { LNBRD }_{i t}+b_{4} \text { APPT }_{i t}+b_{5} \\
& \text { SIZE }_{i t}+b_{6} \text { TOTEQ }_{i t}+e_{i t}
\end{aligned}
$$

Where:

$\mathrm{AR}=$ Abnormal Return

CONST $=$ Constitutional Investment Restrictions

BRDINV = Board Purview Over Investment Decisions

LNBRD $=$ Natural Log of Total Number of Board Members

APPT $=$ Percentage of Board Appointed

SIZE $=$ System Size

TOTEQ $=$ Percentage of Portfolio in Equities

$\mathrm{e}=$ Random Error Term

$\mathrm{i}=$ The "ith" system for $\mathrm{i}=1-81$

$t=$ Time for 1996, 1998, and 2000, respectively

In the results that follow ordinary least squares results are presented as a benchmark for comparison. However, the findings are not discussed as the technique has many shortcomings when estimating panel data.

\section{RESULTS}

\section{Sample Characteristics}

Table 1 below details raw descriptive statistics for the 81 defined benefit public pension funds reporting in the 2001 survey. The contents include measures of central tendency and minimum and maximum values for total portfolio return, system size (market value of assets), and asset allocation patterns. The average rate of return in 2001 was approximately 6.22 percent with a minimum of -3.80 percent and a maximum of 18.90 percent. Reflecting positive skew in the distribution, the mean statistic for the market value of system assets is $\$ 11,429$ million: more than 2.5 times the median estimate of $\$ 4,463$ million. 
TABLE 1

Sample Statistics of Pension Funds (2001 Survey)

\begin{tabular}{|c|c|c|c|}
\hline & Mean & Minimum & Maximum \\
\hline \multicolumn{4}{|l|}{ Portfolio Characteristics } \\
\hline Portfolio Total Return & $6.22 \%$ & $-3.80 \%$ & $18.90 \%$ \\
\hline Market Value of Assets (millions) & $\$ 11,429$ a & $\$ 2.30$ & $\$ 89,247$ \\
\hline \multicolumn{4}{|l|}{ Portfolio Allocation } \\
\hline Domestic Stock & $45.23 \%$ & $0.00 \%$ & $70.00 \%$ \\
\hline International Equity & 12.26 & 0.00 & 25.67 \\
\hline Domestic Bonds & 30.34 & 6.90 & 75.00 \\
\hline International Fixed Income & 1.94 & 0.00 & 10.20 \\
\hline Real Estate Equity & 3.40 & 0.00 & 17.10 \\
\hline Mortgages & 0.72 & 0.00 & 15.00 \\
\hline Alternative Investments & 2.69 & 0.00 & 16.00 \\
\hline Cash & 3.18 & 0.00 & 25.00 \\
\hline Other Investments & 0.23 & 0.00 & 7.70 \\
\hline
\end{tabular}

Note: a Median Statistic $=\$ 4,463$

The large variation in total return may be at least partially explained by the substantial variation in portfolio asset allocations. For example, while the average allocation to domestic equity is slightly more than 45 percent at least one fund allocated nothing to this category. Considering domestic bonds, all 81 systems allocated a portion of assets under control to this class in 2000 with at least one fund having placed nearly 75 percent of all assets in corporate and government debt. In terms of international equity, at least one system allocated over a quarter of total assets to this category. However, no system placed more than 10.2 percent of their portfolio in international fixed income.

Table 2 below gives simple counts for the number of pension funds reporting a particular governance practice in the 2001 survey. Specifically, 11 systems acknowledged the existence of constitutional investment restrictions and 66 funds reported that the board has purview over investment decisions. In addition 38 funds have a board which is primarily composed of appointed membership while 27 systems reported boards with above average levels of membership numbers. 
TABLE 2

Number of Systems with a Governance Characteristic (2001 Survey)

\begin{tabular}{|l|c|}
\hline Governance Characteristic & $\begin{array}{c}\text { Number Reporting (N } \\
\mathbf{8 1} \text { ) }\end{array}$ \\
\hline Constitutional Investment Restrictions & 11 \\
\hline Board Purview Over Investment Decisions & 66 \\
\hline $\begin{array}{l}\text { Boards with Majority of Members } \\
\text { Appointeda }\end{array}$ & 38 \\
\hline Boards with Above Average Membership & 27 \\
\hline
\end{tabular}

Notes:

a Minimum = 0; Maximum = 11: Mean = 3.51; Standard Deviation 2.61.

b Minimum $=5$; Maximum $=26$ : Mean $=9.35$; Standard Deviation 3.58.

\section{Bivariate Results}

Bivariate hypotheses regarding the relationship between governance practices and abnormal return were assessed in two ways for each of the three separate surveys: a) parametric t-tests and One-Way Analysis of Variance (ANOVA) were utilized for categorical explanatory variables, and b) simple correlation coefficients were calculated for continuous predictors. Results are displayed in Tables 3 and 4 below.

Referencing Table 3, highlights include the fact that systems not subject to constitutional investment restrictions earned higher abnormal returns for each of the three surveys. However, only the 2001 survey shows a statistically significant result in panel one with those systems not having such a constraint earning 372 basis points more in risk adjusted returns on average. The second panel shows similar information in relation to board purview over investment decisions variable. However, while all three surveys have results in the expected direction, only the 2000 and 2001 surveys are statistically significant with the latter being the most substantive.

The third panel of Table 3 indicates mixed results for the relationship between abnormal return and continuous governance practice variables. Specifically, board size (total number of board members) is neither statistically nor substantively significant for any 
TABLE 3

Bivariate Results between Abnormal Return and Governance Practices

Panel 1. Constitutional Investment Restrictions

\begin{tabular}{|l|c|c|c|}
\hline Survey & $\begin{array}{c}\text { Investment } \\
\text { Restrictions } \\
\text { (CONST = Yes) }\end{array}$ & $\begin{array}{c}\text { Investment } \\
\text { Restrictions } \\
\text { (CONST = No) }\end{array}$ & t-value \\
\hline $1997(n=81)$ & -0.59 & 0.09 & 0.56 \\
\hline $2000(n=81)$ & -5.13 & -2.86 & 1.32 \\
\hline $2001(n=81)$ & 3.62 & 7.34 & $1.72^{\mathrm{c}}$ \\
\hline \multicolumn{4}{|c|}{ Panel 2. Board Purview over Investment Decisions } \\
\hline Survey & $\begin{array}{c}\text { Board Invests } \\
\text { (BRDINV = Yes) }\end{array}$ & $\begin{array}{c}\text { Board Invests } \\
\text { (BRDINV = No) }\end{array}$ & t-value \\
\hline $1997(n=81)$ & -0.18 & 0.68 & 1.26 \\
\hline $2000(n=81)$ & -3.79 & -.80 & $2.60^{\mathrm{a}}$ \\
\hline $2001(n=81)$ & 5.57 & 12.38 & $5.14^{\mathrm{a}}$ \\
\hline $\begin{array}{l}\text { Panel 3. Pearson r for Continuous Governance Practices and Abnormal } \\
\text { Returns }\end{array}$ & LNBRD & APPT & TOTEQ \\
\hline Survey & 0.10 & -0.13 & -0.06 \\
\hline $1997(n=81)$ & 0.00 & $-0.18^{\mathrm{c}}$ & $-0.22^{\mathrm{b}}$ \\
\hline $2000(n=81)$ & 0.07 & 0.08 & $0.36^{\mathrm{a}}$ \\
\hline $2001(n=81)$ &
\end{tabular}

Notes: The reported tests of statistical significance are two tailed.

a Significant at less than 0.01 level.

b Significant at less than 0.05 level.

c Significant at the 0.10 level.

of the three surveys and percentage of the board appointed is only statistically significant for the 2000 survey. While the percentage of the portfolio allocated to equity investments variable is substantively significant for both the 2000 and 2001 surveys, the relationship are in opposite directions with the latter result being statistically significant at less than the one percent level.

Referencing Table 4, the key elements of interest are that based on $p<.05$, a significant difference exists within comparisons of abnormal return among the four categorizations of system size for the 1997 and 2000 surveys but not the 2001 survey. Furthermore, statistically significant differences exist between the smallest systems (< 100 Million) and larger systems (1.0 - 9.9 Billion) for the 1997 survey. For the 1998 survey, statistically significant differences 
TABLE 4

One-Way ANOVA Comparison of Abnormal Return Sample Means

\begin{tabular}{|c|c|c|c|}
\hline \multicolumn{2}{|l|}{ Panel 1. 1997 Survey } & \multicolumn{2}{|c|}{1996 Abnormal Return a } \\
\hline System Size (SIZE) & $\mathrm{n}$ & $M$ & SD \\
\hline$<100$ Million & 12 & $-1.52^{b}$ & 2.96 \\
\hline 100 - 999 Million & 19 & -0.27 & 2.55 \\
\hline $1.0-9.9$ Billion & 34 & $0.71^{b}$ & 2.22 \\
\hline $10+$ Billion & 16 & -0.09 & 1.89 \\
\hline \multicolumn{2}{|l|}{ Panel 2. 2000 Survey } & \multicolumn{2}{|c|}{1998 Abnormal Return a } \\
\hline System Size (SIZE) & $\mathrm{n}$ & $M$ & SD \\
\hline$<100$ Million & 9 & -3.45 & 5.43 \\
\hline 100 - 999 Million & 20 & $-5.24 c$ & 4.69 \\
\hline 1.0 - 9.9 Billion & 27 & -3.19 & 3.52 \\
\hline $10+$ Billion & 25 & $-1.48^{c}$ & 3.63 \\
\hline \multicolumn{2}{|l|}{ Panel 3. 2001 Survey } & \multicolumn{2}{|c|}{2000 Abnormal Return } \\
\hline System Size (SIZE) & $\mathrm{n}$ & $M$ & SD \\
\hline$<100$ Million & 7 & 4.86 & 7.79 \\
\hline 100 - 999 Million & 19 & 6.23 & 7.75 \\
\hline $1.0-9.9$ Billion & 28 & 7.25 & 6.30 \\
\hline $10+$ Billion & 27 & 7.33 & 6.50 \\
\hline
\end{tabular}

Notes: Scheffe procedure used to detect differences between groups.

a Overall $F$ statistic indicates significant differences exist within comparisons of abnormal returns among the four different categorizations of system size, $p<.05$.

$b$ Third group different from the first group only, $p<.10$.

c Fourth group different from the second group only, $p<.05$.

appear to have existed between the lower side of medium sized funds (100 - 900 Million) and the nation's largest pensions (10+ Billion). Table 4 also appears to mirror the success of the financial markets in the latter part of the 1990 s as the overall proportion of the 81 systems with higher levels of assets (10 + Billion) increases over the time period being analyzed.

\section{Multivariate Analysis}

Table 5 below presents results of the multivariate panel data analysis. OLS point estimates are given as benchmarks for comparisons against the two potential estimations discussed earlier. However, given the violations discussed in the econometric framework section of this paper their interpretation is problematic. And, as noted earlier they are not discussed here. 


\section{F-Test}

The F-test at the bottom of Table 5 tests the difference in mean abnormal return among groups over time. The $F$ values of 0.93 in equation one, 0.88 in equation two, and 0.90 in equation three indicate that there does not appear to be a significant difference in abnormal return across pension funds that are not accounted for by the independent variables in each model.

\section{Regressions and Hausman Specification Test}

Hausman's specification (Hausman Chi-square) tests whether individual effects are correlated with independent variables in a model. Referencing the first equation, the null hypothesis that individual effects are uncorrelated with regressors is not rejected (Hausman Chi-Square $=1.86$ ). This indicates that all of the independent variables in the model are free from the impact of individual effects and implies that the random effect model is best to estimate this equation. The random effect estimation of equation one suggests that both constitutional investment restrictions and board purview over investment decisions have a direct negative impact on financial performance.

Referencing the second equation, when system size is controlled for, the null hypothesis that individual effects are uncorrelated with regressors is still not rejected (Hausman Chi-Square $=1.67$ ). Again, this indicates that all of the independent variables in the model are free from the impact of individual effects and implies that the random effect model is best to estimate this equation. An examination of the constitutional investment restrictions and board purview coefficients reveals little adjustment in terms of magnitude and no change in terms of overall levels of statistical significance.

Referencing the third equation, when the percentage of the portfolio in equity investments is controlled for, the null hypothesis that individual effects are uncorrelated with regressors is once again not rejected (Hausman Chi-Square $=2.19$ ). While both the constitutional investment restrictions and board purview coefficients remain in a negative direction only board purview over investment decisions (BRDINV) remains statistically significant. The magnitude of this point estimate throughout the series of equation estimations indicates that holding other factors constant, the direct impact is approximately 300 basis points whether or not system size and equity are controlled for. 
TABLE 5

Multivariate Analysis with Abnormal Return Regressed on Governance Characteristics (Standard Error)

\begin{tabular}{|c|c|c|c|c|c|c|c|}
\hline & 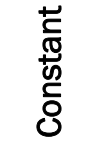 & 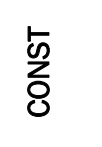 & $\begin{array}{l}\gtreqless \\
\text { 号 } \\
\text { 它 }\end{array}$ & $\begin{array}{l}\text { 是 } \\
\text { ઠิ } \\
\text { 罗 }\end{array}$ & $\frac{5}{\frac{5}{\alpha}}$ & $\frac{山}{\text { ऊ }}$ & 움 \\
\hline \multicolumn{8}{|l|}{ Equation 1d, e } \\
\hline OLS & $\begin{array}{c}3.53 \\
(2.99) \\
\end{array}$ & $\begin{array}{l}-1.62 \\
(1.24) \\
\end{array}$ & $\begin{array}{l}-3.05^{a} \\
(1.05) \\
\end{array}$ & $\begin{array}{c}0.27 \\
(1.25) \\
\end{array}$ & $\begin{array}{l}0.005 \\
(0.01) \\
\end{array}$ & & \\
\hline Fixed Effect & $\mathrm{N} / \mathrm{A}$ & $\begin{array}{l}-2.93^{c} \\
(1.62)\end{array}$ & $\begin{array}{l}-3.19^{b} \\
(1.29)\end{array}$ & $\begin{array}{c}2.45 \\
(1.75)\end{array}$ & $\begin{array}{l}-0.02 \\
(0.02)\end{array}$ & & \\
\hline Random Effect & $\begin{array}{l}6.54^{b} \\
(2.87) \\
\end{array}$ & $\begin{array}{l}-2.24^{b} \\
(1.15) \\
\end{array}$ & $\begin{array}{l}-3.166^{a} \\
(0.95) \\
\end{array}$ & $\begin{array}{l}-0.90 \\
(1.19) \\
\end{array}$ & $\begin{array}{c}-0.012 \\
(0.013) \\
\end{array}$ & & \\
\hline \multicolumn{8}{|l|}{ Equation 2d, e } \\
\hline OLS & $\begin{array}{c}2.62 \\
(3.01)\end{array}$ & $\begin{array}{l}-1.27 \\
(1.25)\end{array}$ & $\begin{array}{l}-2.84^{a} \\
(1.05)\end{array}$ & $\begin{array}{l}-0.52 \\
(1.31)\end{array}$ & $\begin{array}{l}0.003 \\
(0.01)\end{array}$ & $\begin{array}{c}0.83^{c} \\
(0.45)\end{array}$ & \\
\hline Fixed Effect & $\mathrm{N} / \mathrm{A}$ & $\begin{array}{l}2.95^{c} \\
(1.63)\end{array}$ & $\begin{array}{l}-3.18^{b} \\
(1.29)\end{array}$ & $\begin{array}{l}-2.48 \\
(1.77)\end{array}$ & $\begin{array}{l}-0.02 \\
(0.02)\end{array}$ & $\begin{array}{c}0.51 \\
(4.56)\end{array}$ & \\
\hline Random Effect & $\begin{array}{l}5.07 \mathrm{c} \\
(3.00)\end{array}$ & $\begin{array}{l}-2.03^{c} \\
(1.16)\end{array}$ & $\begin{array}{l}-3.04 a \\
(0.95)\end{array}$ & $\begin{array}{l}-1.36 \\
(1.24)\end{array}$ & $\begin{array}{l}-0.01 \\
(0.01)\end{array}$ & $\begin{array}{c}0.83 \\
(0.55)\end{array}$ & \\
\hline \multicolumn{8}{|l|}{ Equation $3^{\mathrm{d}, \mathrm{e}}$} \\
\hline OLS & $\begin{array}{c}1.43 \\
(3.40)\end{array}$ & $\begin{array}{l}-1.04 \\
(1.28)\end{array}$ & $\begin{array}{l}-2.77^{a} \\
(1.05)\end{array}$ & $\begin{array}{l}-0.62 \\
(1.32)\end{array}$ & $\begin{array}{l}-0.004 \\
(0.01)\end{array}$ & $\begin{array}{l}0.80^{c} \\
(0.46)\end{array}$ & $\begin{array}{c}0.02 \\
(0.03)\end{array}$ \\
\hline Fixed Effect & $\mathrm{N} / \mathrm{A}$ & $\begin{array}{l}-2.39 \\
(1.68)\end{array}$ & $\begin{array}{l}-3.15^{b} \\
(1.28)\end{array}$ & $\begin{array}{l}-2.83 \\
(1.78)\end{array}$ & $\begin{array}{l}-0.02 \\
(0.02)\end{array}$ & $\begin{array}{c}0.28 \\
(4.55)\end{array}$ & $\begin{array}{c}0.06 \\
(0.05)\end{array}$ \\
\hline Random Effect & $\begin{array}{c}3.29 \\
(3.32)\end{array}$ & $\begin{array}{l}-1.69 \\
(1.18)\end{array}$ & $\begin{array}{l}-2.98 \mathrm{a} \\
(0.95)\end{array}$ & $\begin{array}{l}-1.57 \\
(1.24)\end{array}$ & $\begin{array}{l}-0.01 \\
(0.01)\end{array}$ & $\begin{array}{c}0.78 \\
(0.55)\end{array}$ & $\begin{array}{c}0.04 \\
(0.03)\end{array}$ \\
\hline
\end{tabular}

Notes

a Significant at less than 0.01 Level; ${ }^{b}$ Significant at less than 0.05 Level; c Significant at less than 0.10 Level.

d F test values for mean differences across groups for Equations 1, 2, and 3 are $0.93,0.88$, and 0.90 , respectively.

e Hausman Chi-square specification test values for Models 1, 2, and 3 are $1.86,1.67$, and 2.19 , respectively. The null hypothesis is individual effects are uncorrelated with other regressors in the model. If the null hypothesis is rejected, the fixed-effect model is superior to the random-effect model. If the null hypothesis is not rejected, the random-effect model is superior to the random-effect model.

\section{COMPARISON TO PRIOR EMPIRICAL RESULTS}

Overall, the finding of a direct association between public pension fund governance practices and financial performance is consistent 
with Albrecht and Hingorani's (2004) study which uses a larger single period cross sectional sample. Furthermore, the existing relationships appear to be similar in direction and comparable in terms of substantive impact. However, there are some divergences when discussing statistical significance.

For example, in their bivariate analysis, Albrecht and Hingorani found that systems whose boards had authority over asset allocation decisions earned 192 basis points less in 1998 risk adjusted return than those systems with trustees not afforded this type of purview. The association continued in a multivariate analysis on the same criterion which yielded a negative direct point estimate of 136 basis points (marginally insignificant at the 10 percent level) for systems with boards involved with asset allocation decisions.

The second panel of Table 3 reflects comparable, although at times larger, differences on a related variable over time and the random effect estimation procedure suggests that the relationship continues in a multivariate framework. The magnitude of the "differences" between the two studies may be a reflection of the fact that the 2001 survey did not contain separate items for board authority over asset allocation decisions and board responsibility for directly investing system assets. ${ }^{15}$ Thus, the somewhat simpler variable of board authority over investments may be capturing multiple factors.

Considering other governance variables, the statistically insignificant -0.01 coefficient in Table 5 for the percentage of the board appointed is similar to Albrecht and Hingorani's finding of a statistically significant -0.02 for the same measure. Furthermore, the -1.57 (statistically insignificant) point estimate for board size is in line with Albrecht and Hingorani: -1.95 (statistically significant). In terms of the random effect estimation procedure, system size in this study does not replicate the statistical significance of the previous work ( 0.57 for the natural log for system assets), but the direction is comparable. The same conclusion can be reached in terms of constitutional investment restrictions. The point estimate is -169 basis points in the third equation of Table 5 (statistically insignificant). By way of comparison, Albrecht and Hingorani found that the presence of prudent policies reduced 1998 risk adjusted returns by 118 basis points (statistically insignificant). ${ }^{16}$

A final mention should be made about the lack of evidence in Table 5 for a direct impact on abnormal return for the percentage of 
the portfolio devoted to equity investments. While the direction and magnitude is similar to that found by Nofsinger (1998), the result is at odds with Albrecht and Hingorani (2004) who find a statistically significant coefficient (-0.05) on an identical measure holding other factors constant. However, in relation to the overall hypothesis, an argument can be made that the statistically insignificant four basis point impact, holding other factors constant, is not as substantive as the impact of governance practices on risk adjusted financial performance.

\section{CONCLUSION AND DISCUSSION}

The purpose of this study was to extend the work of Albrecht and Hingorani (2004) which examined the effects of governance practices and investment strategies on state and local government pension fund risk adjusted financial performance. In that investigation, the researchers tested the mediating "theory" of Useem and Mitchell (2000) on a theoretically separate criterion and concluded that direct governance practice impacts not only exist but possibly dominate the data generation process.

The results as outlined here provide further evidence of such a conclusion and continue to support prior policy recommendations. For example, given these results policymakers should reevaluate the continuation of board authority over investment decisions and perhaps consider more outside managers with greater levels of expertise. Barring this, those charged with pension issues should consider training for those administrators involved with the investment area of pension fund management.

There is also some evidence to support the reconsideration of constitutional investment restrictions and composition of boards of trustees. While not statistically significant, both factors are substantive enough in terms of basis points to warrant further attention. These findings, particularly results pertaining to the percentage of the board appointed, should be considered if and when the national retirement system is ever allowed to be managed in a manner that mimics state and local government pension funds.

An important question is why a comparison study such as this matters? The fundamental answer is that conclusions must be interpreted relative to the definition of financial performance. For example, total rate of return, as a pension outcome, does not account for risk tolerances, liability structures, or value added practices. The 
decision to use total return is equally critical when considering that this outcome variable, in all probability, does include trends occurring in the marketplace. Combinations of these factors are likely to systematically reflect the influence of attributes, other than that of governance characteristics, resulting in a positive bias for those systems with higher tolerances for risk.

A number of writers in the areas of investment management, performance measurement, and performance evaluation indicate that all of these factors should be considered when making individual or peer comparisons and suggest adjusting the total return outcome by an appropriate "benchmark return" that ledgers their existence. The "abnormal return" measure used here in effect standardizes total return by treating risk and liability factors endogenously. Conceptually abnormal return is a separate construct of financial performance apart from total return. Empirically, the measure is arguably more appropriate for peer comparative purposes (Ambachtsheer, 1994, p. 22). ${ }^{17}$

Using either measure as a criterion variable implies a separate set of inherently valued outcomes if preferences are expressed for one type of result over another. For example, the fact that increases in investment income from public funds can facilitate improvements in pension funding levels, increases in benefits, or decreases in taxes is not in dispute. Higher total returns are better outcomes. However, in terms of peer comparison, the choice of performance measure should reflect assumptions underlying the units of analysis.

In reality, public pensions are heterogeneous institutions differing substantially in liabilities, assets, and funding ratios (GFOA, 2000, p. 4-6). Well-funded systems with substantial assets and no immediate liabilities may prudently incur risk of principal monies in the current period by pursuing aggressive investment strategies that bolster total return over the long run. However, these same risky strategies are not necessarily appropriate for mature systems expecting to pay substantial benefits in the near future. In the end this is what we hope to have accounted for.

\section{NOTES}

1. See Albrecht and Hingorani (2004), page.677.

2. Public Pension Coordinating Council, 2001 Survey of State and Local Government Employee Retirement Systems, [data on-line]; 
available from http://ppcc.grsnet.com; accessed 21 February 2003.

3. A poor dichotomous split is defined as such when more than 90 percent of responses fall into one category. When such a condition occurs, the honest correlation between a continuous variable and a dichotomous variable is essentially deflated as the highest correlation that could be obtained is well below one. See, for example, Tabachnick and Fidell (2001) pages 57-58. Previously examined governance variables exhibiting this condition include whether or not the pension system operates under prudent person or prudent expert restrictions, and whether or not the system obtains independent performance evaluations. The condition was most prevalent for the 2001 survey.

4. For example, items related to board purview over asset allocation decisions and direct responsibility for the investment of system assets are measured in the 1997 and 2000 surveys but not the 2001 survey.

5. The other investments category is a single item for the 2001 survey. For the 1997 and 2000 surveys the other investments category included both fixed income and equities as categories. Both classes were combined to create a single other investments category for each of these surveys.

6. Indexes (a), (b), and (h) were obtained from Global Financial Data [data on-line]; available from: www.globalfindata.com; accessed 05 January 2003. Indexes (c), (d), and (e) were obtained from the Illinois Municipal Retirement Fund 2000 Comprehensive Annual Financial Report [report on-line]; available from: www.imrf.org; accessed 05 January 2003. The index for (f) was obtained from Wilshire Associates Incorporated [data on-line]; available from www.wilshire.com; accessed 12 November 2002. The index for (g), alternative and other investments, was created by chain linking quarterly returns for the NCREIF property index [data-online]; available from: www.ncreif.com; accessed 12 November 2002.

7. Beyond empirical findings the expectation is supported by noting that such limitations often confound modern investment management practices. 
8. The expectation is further supported by noting that Albrecht and Hingorani (2004) found an inverse relationship between board size and financial performance.

9. The study does not distinguish between those appointed by a governing body (e.g., legislature or council) or Chief Elected Official (e.g., Governor or Mayor). The 2001 survey does not capture this information beyond those simply appointed.

10. The original PPCC measures are denoted as dollar amounts. The reason why we measure system size with an ordinal variable is to avoid a minimal change in size over time, which may not have much impact on return, but may produce a severe consequence on a coefficient. The minimal change of asset size over time creates a missing time-varying variable in the disturbance of a cross-sectional time-series model, which will cause a biased coefficient when conducting a multivariate analysis. The actual categorizations are identical to those given in all three GFOA Survey Reports.

11. See, for example: Munnell and Sunden (2000) page 159 and pages 163-164.

12. The direction of influence would ultimately depend on whether or not systems actually capture higher total returns for higher levels of assumed risk. If they did not, the influence of equity investments on abnormal return (in terms of systematic explanation) could be expected to be negative.

13. For a complete description of data screening procedures in relation to the 2000 Survey see Albrecht (2001) pages 80-88.

14. See for example, Hsiao (1986) page 25.

15. See note 4 above.

16. An important point to note is that Albrecht and Hingorani (2004) examined both equity and international strategies. The discussion of point estimates here refers to their analysis of equity investment strategies only.

17. There is no intention of suggesting that abnormal return, as defined here, is the best or even most appropriate measure of financial performance. Ideally traditional measures of risk such as "beta" would be used. However, this is not possible given the lack of time series data (Nofsinger, 1998). Our only assertion is 
that the "abnormal" measure is arguably an improvement to that which has already been used.

\section{REFERENCES}

Albrecht, W. G. (2001). Effects of Governance and Investment Strategies on Public Pension Outcomes. Unpublished PhD Dissertation. Baton Rouge, LA: Southern University.

Albrecht, W. G., \& Hingorani, V. L. (2004). "Effects of Governance Practices and Investment Strategies on State and Local Government Pension Fund Financial Performance." International Journal of Public Administration, 8 \& 9 (27): 673-700.

Ambachtsheer, K. P. (1994, November-December). "The Economics of Pension Fund Management," Financial Analysts Journal: 2131.

Zorn, P. (1997). 1997 Survey of State and Local Government Employee Retirement Systems Survey Report. Chicago, IL: Government Finance Officers Association.

GFOA Research Center (2000, April). 2000 Survey of State and Local Government Employee Retirement Systems Survey Report. Chicago, IL: Government Finance Officers Association.

Public Pension Coordinating Council (1997). 1997 Survey of State and Local Government Employee Retirement Systems Survey Report. Chicago, IL: Government Finance Officers Association.

Public Pension Coordinating Council (2001). 2001 Survey of State and Local Government Employee Retirement Systems Survey Report. Chicago, IL: Government Finance Officers Association.

Harris, J. D. (2002, March ). 2001 Survey of State and Local Government Employee Retirement Systems Survey Report [Online]. Available at http://ppcc.grsnet.com.

Hsiao, C. (1986). Analysis of Panel Data. New York: Cambridge University Press.

Mitchell, O. S. \& Hsin, P. L. (1997). "Public Pension Governance and Performance." In S. Valdes-Prieto (Ed.), The Economics of Pensions: Principles, Policies, and International Experience (pp. 92-123). New York: Cambridge University Press. 
Munnell, A. H., \& Sunden, A. (2001). "Investment Practices of State and Local Pension Funds: Implications for Social Security Reform." In 0 .S. Mitchell, \& E. C. Hustead (Eds.), Pensions in the Public Sector. (pp. 153-194). Philadelphia, PA: University of Pennsylvania Press.

Nofsinger, J. R. (1998). "Why Targeted Investing Does Not Make Sense!" Financial Management, 27 (3): 87-96.

Tabachnick, B.G., \& Fidell, L.S. (2001). Using Multivariate Statistics (4th ed.). Needham Heights, MA: Allyn \& Bacon.

Useem, M., \& Hess, D. (2001). "Governance and Investments of Public Pensions." In 0 .S. Mitchell, \& E. C. Hustead (Eds.), Pensions in the Public sector (pp. 132-152). Philadelphia, PA: University of Pennsylvania Press.

Useem, M., \& Mitchell, O. S. (2000). "Holders of the Purse Strings: Governance and Performance of Public Retirement Systems." Social Science Quarterly, 81 (2): 489-506.

Yermack, D. (1996). "Higher Market Valuation of Companies with a Small Board of Directors." Journal of Financial Economics, 40 (2): 185-211. 